\title{
Water Beneath Deserts: Keys to the Past, A Resource for the Present
}

\author{
by Arie S. Issar and Ronit Nativ
}

Huge aquifers containing about $100,000 \mathrm{~km}^{3}$ of water of low salinity extend under the deserts of Africa and Australia, and similar aquifers are also found beneath many other arid and semi-arid regions. The residence time for the fossil waters in these aquifers is tens of thousands of years, so they are in essence non-renewable resources. The authors suggest that mining of aquifers should be undertaken but only within the framework of a long-term development plan. In addition to their obvious social and economic benefits, these aquifers can provide invaluable information about the processes and climatic conditions under which they formed. (Ed.)

\section{Should Fossil Groundwater be Mined?}

Many arid and semi-arid areas of the world are underlain by thick layers of clastic and carbonate sedimentary rocks saturated with huge volumes of fresh and brackish groundwater (Table 1, Fig. 1), a considerable part of which can be used for agricultural and industrial development. Most of this is "fossil" or paleowater that entered the aquifers when humid climatic conditions prevailed in these regions. Since present recharge rates are negligible, this water can be regarded as one-time, non-renewable resource, the exploitation of which should be carefully planned.

Vany hydrogeologists, water engineers, and decision makers caution against over-pumpage and over-exploitation. For them draining (mining) an aquifer is too radical or dangerous and should be avoided. Thus, the first obstacle that a "nonconservational" hydrogeologist or planner may have to overcome is a psychological one expressed by the attitude that since "water is the source of life, what will we do when this resource is exhausted?" On the other hand, the feasibility of groundwater mining should be evaluated, we suggest,

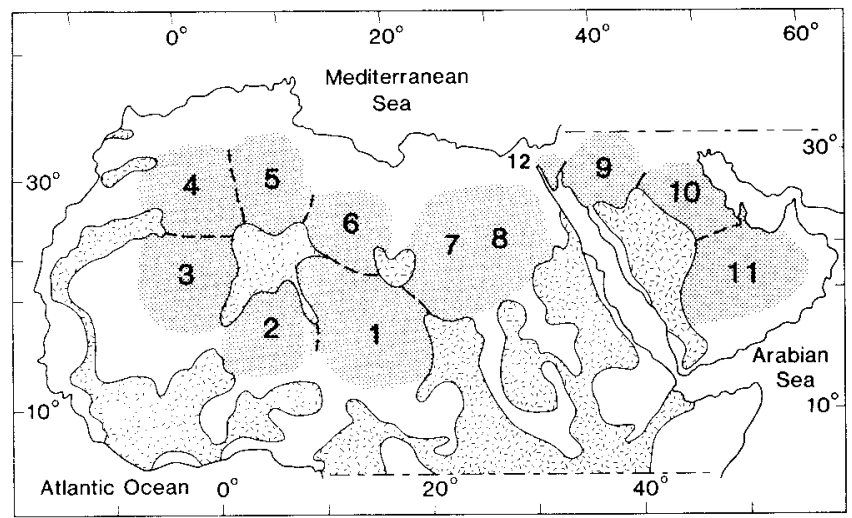

Figure 1: Major groundwater basins of the Sahara and A rabia. Modified from Burdon, 1977. 1- Chad, 2- Niger, 3Tanezrouft, 4- Western Erg, 5- Eastern Erg, 6- Fessan, 7Kufra, 8- Western Desert, 9- Nafud, 10-Riyadh, 11Rub-al-Khali, 12 - Sinai and Negev Deserts. Dashes crystalline basement. using the same criteria as for other economic minerals such as oil, coal or iron (Burdon, 1977; Issar, 1981a; and Tsur and Issar, in press).

The volume of water required to sustain life is, in fact, very small compared to the total amount used for all other economic activities, such as agriculture and industry. These small quantities can always be provided either through desalination of local saline water, or by imports. Moreover, it can be argued that water for irrigation in arid countries has the same basic economic importance as fuel and metals in industrialized and cold countries.

Large aquifers that underlie arid regions are also important for other reasons. In deserts, for example, they buffer the fluctuation in availability of surface-water resources due to the annual climatic variations that characterize arid regions. Most such changes can be related to the location of these regions along the boundaries of high-pressure climatic belts. Variations in the thermodynamic conditions of the atmosphere result in the migration of these belts, which in turn affects precipitation, availability of water and, thus, conditions of life.

The code name for survival in desert regions is storage. Groundwater is a blessing in the desert because of its natural storage features. Each grain of sand in an aquifer forms a minute retarding dam, lengthening the water path and reducing the flow velocity. The overlying rocks protect groundwater from evaporation, which is the governing process in arid zones. Therefore, paleowater should be used to assist agricultural communities living along desert borders in levelling of their income, even during drought periods, or in abandoning gradually their nomadic life-style (Tsur and Issar, in press).

Obviously, utilization of paleowater should be implemented only on a firm economic basis, and in harmony with local environmental and social conditions. Experimental and demonstration farms based on fossil water may be a triggering factor in promoting a change in society, improving its suitability for survival in a changing climate and world. We maintain that ancient ways of life can be conserved as long as society is willing to pay the costs involved. For ancient societies, the price was starvation, wars and plagues, whenever resources became scarce.

Such economic changes cannot be imposed upon a society, but must take place gradually. Groundwater is an ideal means to trigger and support such an evolution. It is available over large regions, often in close vicinity to potential consumers, and does not require large investments in big dams or lengthy pipes and canals. Obviously, wherever shallow aquifers exist, priority should be given to them, even though their storage capacity is limited. In the long run, however, fossil water in deep regional aquifers has to be developed. Careful planning is needed so that it not only forms a source of water, but also provides the focus for research on efficient water use, both socially and physically. In more developed regions, a master plan that integrates a comprehensive approach to deep aquifer management and utilization needs to be formulated and followed. 
TABLE 1: Groundwater characteristics and reserves in great sedimentary basins. After Forkasiewicz and Margat (1982).

\begin{tabular}{|c|c|c|c|c|c|c|c|}
\hline \multirow{2}{*}{ Sedimentary Basir } & \multirow{2}{*}{$\begin{array}{c}\text { Area } \\
10^{3} \mathrm{~km}^{2}\end{array}$} & \multirow{2}{*}{$\begin{array}{l}\text { Aquifers } \\
\text { (thickness in } m \text { ) }\end{array}$} & \multicolumn{3}{|c|}{$\begin{array}{c}\text { Mydrodynamic Parameters } \\
\text { (Ext reme Values) }\end{array}$} & \multirow{2}{*}{$\begin{array}{c}\text { Recharge } \\
10^{8} \mathrm{~m}^{3} / \text { year }\end{array}$} & \multirow{2}{*}{$\begin{array}{c}\text { Quantity } \\
\text { Stored } \\
\left(\mathrm{m}^{3}\right)\end{array}$} \\
\hline & & & $\begin{array}{c}\text { Transmissivity } \\
\left(\mathrm{m}^{2} / \mathrm{d}\right)\end{array}$ & $\begin{array}{l}\text { Storativity } \\
\left(10^{-3}\right)\end{array}$ & $\begin{array}{l}\text { Effective } \\
\text { porosity (8) }\end{array}$ & & \\
\hline $\begin{array}{l}\text { Nubian sandstone: } \\
\text { Kufra (Libys) } \\
\text { New Valley (Egypt) }\end{array}$ & 1800 & $\begin{array}{l}\text { Sandstones and } \\
\text { Sands (Cambrian to } \\
\text { Up. Cretaceous } \\
(3500 \mathrm{~m})\end{array}$ & $\begin{array}{l}250-3000 \\
500-5500\end{array}$ & $\begin{array}{l}=0.5 \\
0.1 \text { to } 1\end{array}$ & $\begin{array}{r}11-25 \\
10\end{array}$ & 10 & $6 \times 10^{22}$ \\
\hline Austrulia & $1700^{\circ}$ & $\begin{array}{l}\text { Sand and sandstone } \\
\text { Trias-Cretaceous } \\
(3000 \mathrm{~m})\end{array}$ & $1-2000$ & 0.01 & & 11 & $2 \times 10^{13}$ \\
\hline $\begin{array}{l}\text { Western Sahara: } \\
\text { Upper complex }\end{array}$ & 350 & $\begin{array}{l}\text { Sand, sandstone } \\
\text { (Up. Cretaceous - } \\
\text { Yincene) }\end{array}$ & $350-25000$ & 0.5 to 150 & $20-30$ & 5.8 & $6 \times 10^{13}$ \\
\hline $\begin{array}{l}\text { Continental Inter- } \\
\text { calation }\end{array}$ & 600 & $\begin{array}{l}\text { Sand, sandstonc, } \\
\text { sandy clay } \\
\text { (Lower Cretacoous) }\end{array}$ & $500-2600$ & 1 to 50 & 20 & 2.7 & \\
\hline $\begin{array}{l}\text { Niger (Continental } \\
\text { Interesigtion) }\end{array}$ & 500 & $\begin{array}{l}\text { Sand and sandstone } \\
\text { (Upper Cretaceouss) } \\
\text { (to } 1000 \mathrm{~m}-\mathrm{Av} .500 \mathrm{~m})\end{array}$ & $1-1000$ & 5 & $5-10$ & 8 & \\
\hline Senegal-Mauritania & 500 & $\begin{array}{l}\text { Sand and sandstone } \\
\text { (Masstrichtian) } \\
\text { (to } 1000 \mathrm{~m}-\text { av. } 200 \mathrm{ml})\end{array}$ & 40-1700 & 0.1 to 0.3 & 5 & 1.3 & $3.5 \times 10^{12}$ \\
\hline
\end{tabular}

\section{Using Confined Aquifers}

Aquifers containing paleo-groundwater are in many cases artesian, and one of the first questions to be resolved is whether water should be pumped or simply allowed to flow (Fig. 2). Initially, the decision has to be taken on the basis of cost-benefit ratio. It should be stressed, however, that the benefits are quite flexible and are often the result of other decisions or development policies. For example, water quantities pumped from an artesian well can be several times larger than those that flow out under natural pressure. Traditional methods are generally wasteful and may also cause environmental hazards. Potential users often have to choose between investing in more advanced methods (benefiting from an efficient water use) and wasting a resource with cheaper utilization techniques. The Great Artesian Basin of Australia, where many wells were drilled and allowed to flow, exemplifies this dilemma (Australian Water Resources Council, 1975).

An important relationship exists between water-utilization mode and aquifer response. As most of these aquifers are confined, their storativity coefficient is very low (in the order of magnitude of $10^{-4}$ ). This means that a relatively small amount of water withdrawn from an aquifer can cause a significant decline of piezometric head in the pumping well (Fig. 3). The reason is that the release of groundwater in a confined aquifer is primarily the result of pressure reduction rather than of draining the saturated layers.

When water withdrawal is constant, the decline in time of the piezometric head will follow an exponential curve. Each increase in pumping will cause it to drop abruptly. Once the piezometric head reaches the bottom of the overlying confining laver, the aquifer becomes unconfiner, and its storativity coefficient reflects its effective porosity, which is in the order of magnitude of 0.1 . This change means a remarkable increase in the quantity of water that can be withdrawn from the aquifer per unit of drawdown. Once the aquifer geometry and hydraulic parameters are determined, the timing of this change can be forecast fairly accurately and checked using calibration prncedures. The forecast can then be used in economic models that help to optimize water use.

Obviously, models of hydrological behaviour of an aquifer must be based on measured parameters and known boundary conditions. This requires the investment of money and time, especially when locating exploration wells and during the study of pumpage and related aqui fer response.

\section{Recharge, Flow and Discharge}

The dominant factor governing flow regime in aquifers is the difference in piezometric head between recharge and discharge zones (Burdon, 1977). In fossil aquifers this difference is residual, but it still exists even though recharge at present is very small (Lloyd and Miles, 1986). It is primarily due to the difference in elevation between the outcrop area of the aquifers and that of their outlet.

Recharge areas extend along the margins of ancient continents or Precambrian shields, as in Saudi Arabia (Burdon and Otkun, 1968; Beaumont, 1977), the Sinai and Israel (Issar et al., 1972), the Western Desert of Libya, eastern and central Sahara (Wright et al., 1982; Himidia, 1970; Klitzsch et al., 1976), and Brazil (Reboucas, 1978). In some places, such as in the western Sahara (Gonfiantini et al., 1974) and the Great Artesian Basin in Australia (Calf and Habermehl, 1983), fold chains along basin margins expose the aquifer layers, thus forming an additional recharge area.

Groundwater flow in deep aquifers is characterized by low velocities and long distances between recharge and discharge zones. The velocity depends on hydraulic conductivity, rock porosity, and hydraulic gradient. Most regional aquifers are composed of sandstone with an effective porosity of about $10 \%$ and a characteristic hydraulic conductivity of $1 \mathrm{~m} / \mathrm{d}$. The very low hydraulic gradient characteristic of many of these vast basins, together with their low hydraulic conductivity, results in groundwater movement of only a few metres a year. Consequently, groundwater located a few hundreds of kilometres away from the recharge area may be tens of thousands of years old, as was first confirmed by ${ }^{4} \mathrm{C}$ dating in the Western Desert of Egypt (Munnich and Vogel, 1962; Degens, 1962).

The presence of a discharge area for groundwater allows the flushing of saline seawater and its replacement by fresh meteoric water. In the northern Sahara and Saudi Arabia, continental margin sediments became saturated with seawater when the Tethyan ocean covered these basins, primarily during Jurassic, Middle to Late Cretaceous, and Paleogene times. The marine encroachment resulted in the advancement of the subsurface interface between saline and fresh water.

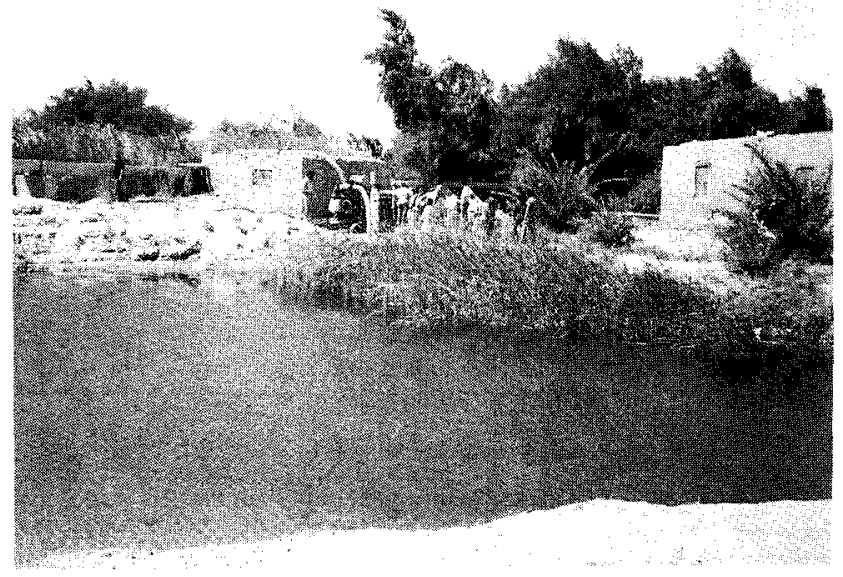

Figure 2: An artesian well in the Kharga Oasis, Western Desert of Egypt. Water is pumped into a concrete conduit, but leakage from corroded pipes has created a pond. 


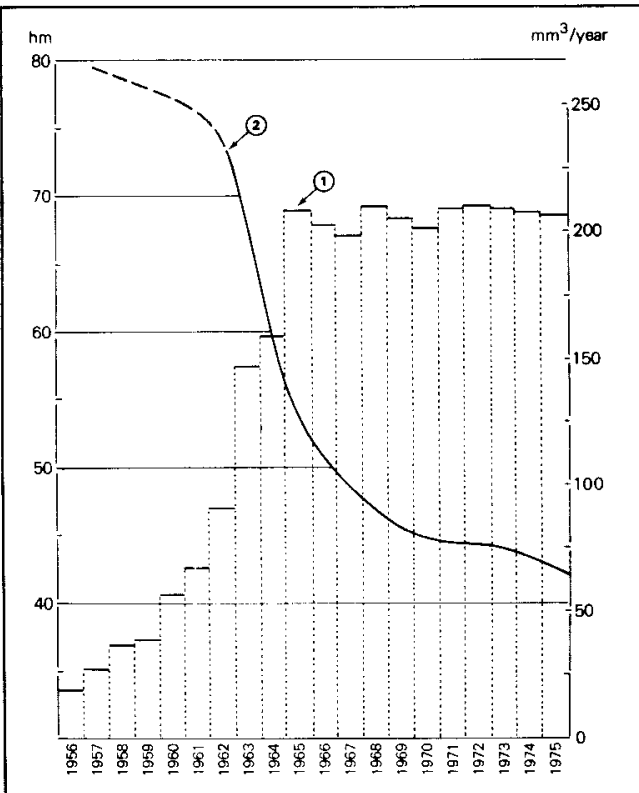

Fiqure 3: Exploitation of the deep Nubian sandstone aquifer Nubia, Western Desert of Egypt. 1) Trends in annual withdrawals from the deep wells at the oases of Kharga and Dakhla. 2) Changes in hydraulic head at Kharga. hm - elevation above mean sea level. From Margat and Saad (1984).

In Israel and the Sinai during the Middle and Late Cretaceous, any fresh water would have been flushed out from Lower Cretaceous sediments by saline seawater. The sea advanced and retreated over a flat area, resulting in extensive lagoon-like sabkhas. As the sea finally retreated by the end of the Paleogene, seawater could not be flushed out, unless an outlet was available in the downstream areas.

Discharge could have been by upward leakage through a semi-confined layer to overlying aquifers with lower hydraulic heads, as happened in Saudi Arabia (Bakiewicz et al., 1982; Lloyd and Miles, 1986). Discharge may also have taken place along regional faults as in the Rift Vally and in Sinai (Issar, 1979, 1981b), through a fracture system as in Australia (Habermehl, 1983), or through anticlinal highs into desert depressions as in the Central Sahara (Klitzsch et al., 1976). Discharging groundwater often formed swamps (sabkhas, chotts) at the outlet area, or travertine mounds along fault lines (Williams and Holmes, 1978).

The location of discharge zones controls water quality in these fossil aquifers. Regions between recharge and discharge zones contain fresh to slightly brackish water, whereas the same layers if flushed contain either seawater or brines (Burdon and Otkun, 1968; Bakiewicz et al., 1982; Beaumount, 1977; Wright et al., 1982; Himidia and Diab, 1979). Beneath flushed aquifers, brines can also be found in deeper layers that for hydraulic or stratigraphic reasons were not drained (Nativ, 1984).

Flushing processes occurring at recharge zones also control the displacement of oil by meteoric water. This can be demonstrated in Eromanga Basin of Queensland (Fig. 4) and in the Sinai and Negev where many oil wells in typical anticlinal structures revealed only traces of petroleum, whereas the same layers in similar anticlines in unflushed zones, or in downfaulted blocks inside the Suez Rift Valley contained oil (Issar, 1979, 1981b).

\section{Mineralization Due to Groundwater Flow Through Fractures}

Mineralization is an interesting feature related to areas of groundwater outflow along regional fault lines (Fig. 5). Because when observed at the surface it is not prominent enough to attract the exploration or hydrogeological interest, this mineralization has not received the attention it deserves. However, it contains much information and might even become a clue to economic deposits located at greater depths.
Investigations in Israel have documented secondary calcite veins enriched with iron and manganese, and with traces of other metals like $\mathrm{Cu}, \mathrm{Zn}, \mathrm{Ni}$ and $\mathrm{Co}$ along major transverse fault lines crossing the Negev Desert into the Sinai (Shraga, 1971; Bartov, 1974; Issar, 1983; Ilani et al., 1987a; Avigur, 1987). Some of these veins contain high $U$ anomalies (Ilani et al., 1987b). Fossil groundwater may have dissolved these metals while flowing through sandstone high in metal oxides. Mineralization may also have occurred at depth, due to combined intrusion and faulting, permitting groundwater emerging along these faults to carry minerals leached from concentrated ore bodies at depth (Ilani et al., 1987b).

\section{Groundwater and Karstification}

In the Negev Desert, deposition of secondary calcite relates to karst phenomena at depth in earbonate rocks that overlie sandstone aquifers (Avigur, 1987). Karst mineralization in the area is restricted to tectonic zones along which fossil groundwater from a sandstone aquifer at depth ascended (Issar, 1983). Under the arid climate this unique karstic process, which proceeded from depth upward, has been preserved. Indeed, present-day water from the Lower Cretaceous Nubian Sandstone aquifer here contains an average of $55 \mathrm{mg} / 1$ of free $\mathrm{CO}_{2}$, indicating a dissolution potential.

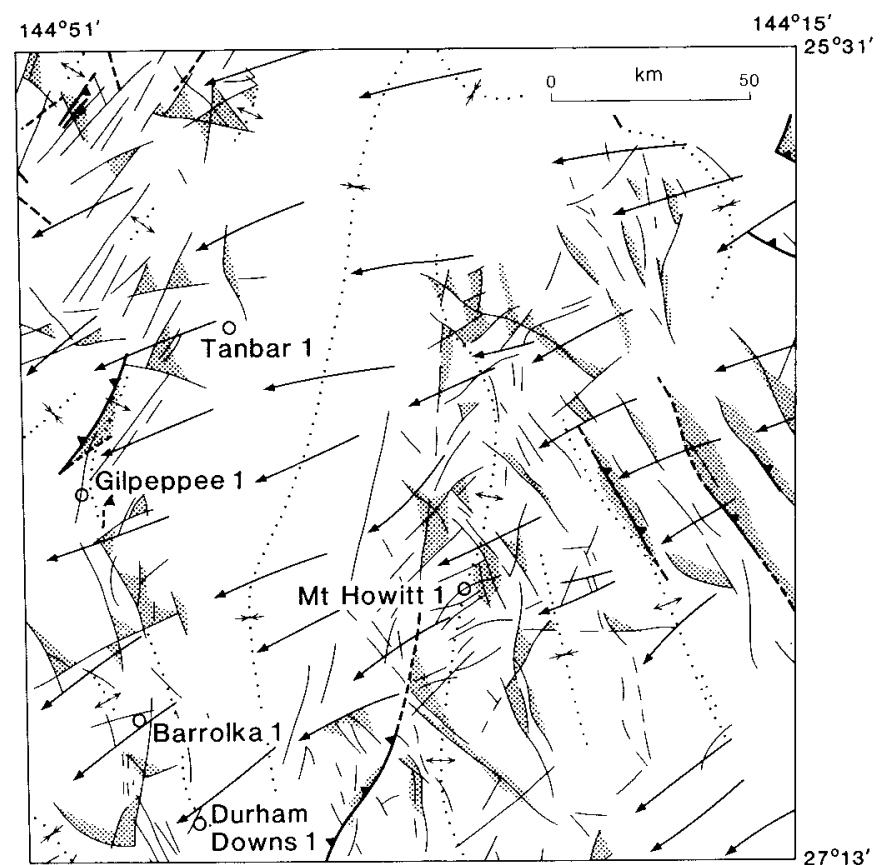

Typical regional groundwater flow-path (local disturbances due to faults not shown)

Area of possible groundwater stagnation. .............

Anticline (concealed) $\ldots \ldots \ldots \ldots \ldots \ldots \ldots \ldots \ldots \ldots \ldots \ldots \ldots$

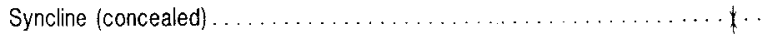

Fault determined by seismic surveys and/or geological reconnaissance (downthrown side indicated).

Inferred fault determined by seismic surveys and/or geological reconnaissance.

Landsat interpreted linear features.

Petroleum exploration well

Figure 4: Geological structure, regional groundwater flow directions, and zones of groundwater stagnation in aquifers in the Lower CretaceousJurassic sequence of the central Eromanga Basin, Queensland. After Senior and Habermehl (1980). 


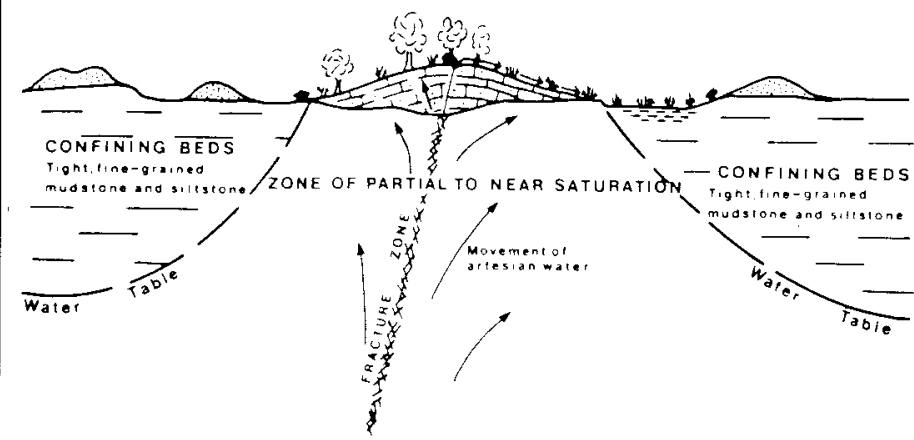

Figure 5: Schematic cross section through a mound spring where groundwater escapes from a confined aquifer along fault lines and precipitates mostlu calcite in a mound around the spring outlet. From williams and Holmes (1978).

Issar (1983) suggested that the formation of the big erosion cirques that breached some of the Negev anticlines was triggered by ascending karst processes. Caverns were developed along steep anticlinal flanks cut by regional transverse faults that formed an outlet for ascending groundwater. Subsequent groundwater flow washed out the sand, resulting in the collapse of the limestone cover. The big depressions in the Western Desert of Egypt (Kharga, Dakhla and Bahariya) are also areas of fossil-water emergence and could have been formed by a similar mechanism (Said, 1962), with wind being the excavation agent.

\section{Reconstructing Paleoclimates from Fossil Water}

The nature of the environment that existed when precipitation infiltrated into regional fossil aquifers can be deduced with the aid of oxygen, hydrogen and carbon isotope analyses of groundwater. This information can be derived from both absolute values and relative ratios of heavy and light isotopes (Fontes, 1980, 1981; Gat, 1981a), which often differ from present values and ratios. In most cases, groundwater isotope ratios in these deep aquifers are more depleted than those in shallow aquifers currently being recharged. This may indicate that either average temperatures of paleoenvironments were lower, or that the elevations of past recharge areas were higher than today. Different precipitation regimes may also have characterized these basins. Reduction in ${ }^{13} \mathrm{C}$ content in fossil groundwater suggests a higher level of soil-organism production.

Sonntag and others (1978) studied the paleoclimate that dominated the Sahara Desert during the last glacial period. According to their studies, fossil groundwater beneath the Sahara plots along a deuterium excess line of $+10 \%$. They also observed a gradual depletion of $18 \mathrm{O}$ and deuterium in groundwater from the western to eastern Sahara. This they attributed to a continental effect, assuming that the rain that recharged the aquifers was generated by air masses from the Atlantic Ocean. The farther these masses moved to the east over the desert, the more isotopically depleted became their water vapour.

In the Sinai and the Negev, fossil groundwater also has a deuterium excess of $+10^{\circ} \% 0$ (Gat and Issar, 1974), whereas currently recharged groundwater has an excess of $+20 \%$ (Fig. 6). Gat (1981b) suggested that this deuterium excess is indicative of rain derived from air masses that moved over a relatively warm Mediterranean sea during glacial times. Extensive rainfall during spring and autumn, when the sea is warmer relative to the atmosphere, could have resulted in similar isotopic compositions.
Wodern precipitation in the Negev and the Sinai is mainly derived from air masses coming from the north and northwest, i.e. from the Mediterranean. Sometimes, however, air masses cross the region along west to east paths, and their precipitation is isotopically similar to that of the paleowater (Leguy et al., 1983). Based on this similarity, Issar and Gilead (1986) suggested that during the last glaciai period, when the Nubian Sandstone aquifer of the Sinai (Fig. 7) was recharged, most precipitation reaching the area was derived from air masses traveling a more southerly route than the northwest and north trajectories that are most common today. The retreat of the Mediterranean Sea then exposed the northern Sinai shelf, resulting in the formation of sabkhas. Airborne dust from the Sahara, together with salts enriched with gypsum, was carried along this southern route into the Negev. The dust was deposited as loess, and subsequent rain leached the gypsum into the subsurface, accounting for the high $\mathrm{SO}_{4}$ content of the fossil groundwater (Issar and Bruins, 1983; Issar and Gilead, 1986).

\section{Wells or Galleries?: Modes of Operation}

Past exploitation of fossil groundwater was through the use of linear chains of wells, referred to locally as ghanats (qanats) or foggaras. This method was developed in Iran to use the water flowing in alluvial fans before it reached saline marshes at the fan fronts (Ambroggi, 1966), and it was used also in the western oases of Egypt. Similar ghanats have also been found in the southern Arava $R$ ift Valley. One group is aligned in a north-south direction, perpendicular to the general flow of groundwater in the alluvium, and the other extends westwards from the fault escarpment into the rift valley. The latter orientation puzzled the original investigators because it did not appear to drain any significant alluvial fan. The enigma was solved when it was found that this direction extended perpendicular to the drainage area of the Nubian Sandstone aquifer.

Planning development of this region raises the question of using the Nubian Sandstone as a future water source. The use of conventional pumpage methods would mean mining a non-renewable water resource. Consequently, the inevitable drop of the piezometric head would lead to an increase in pumpage costs and technical problems, to the point where this source would become economically impractical. These

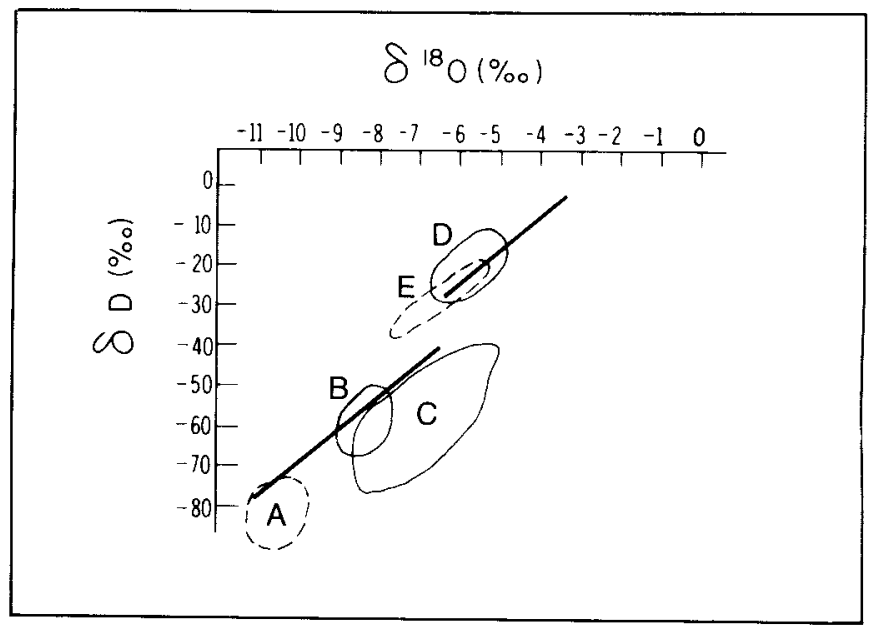

Figure 6: Deuteriummoxygen ratios of groundwater from the Sinai and the Negev. The lower Iine (paleometeoric water) has a deuterium excess of $10 \% \%$, compared to the upper 1 ine for currently recharged groundwater with a $D$ excess of $+20 \%$. Paleowater from the Western Desert ( $A$ ) and Negev and Sinai (B); (C) Modern SW-moving rainstorms in the Negev; (D) Modern NW-and W-moving rainstorms in the Negev; (E) Precipitation and groundwater in central and northern Israel. 
problems are made more acute in the Arava Valley because the Nubian aquifer extends from the rift valley to the west beyond the high escarpment of the main fault line. Consequently, the area feasible for pumpage is restricted to a topographically low and narrow band along the fault face or, in some places, to strips along the main wadis that breach the escarpment. Clustering of many wells in such a small area could have resulted in a very rapid decline of the groundwater piezometric head.

A suggestion was made by Issar and Melamed (1983) to adopt the ancient technique of galleries. The proposal included the driving of mining galleries into the escarpment, pumping out the draining water, and the continuous extension of the galleries tens of kilometres westward from the rift valley, below the Negev Highlands. To maintain a constant groundwater influx into a gallery, a continuous lengthening of it is required, making use of a service gallery overlying the draining gallery. Clearly initial costs would be high, requiring a certain threshold quantity of water to be maintained to keep it economic. In the Arava Valley this quantity amounts to $300 \times 10^{6} \mathrm{~m}^{3} / \mathrm{yr}$. With a total water reserve of about $70 \times 10^{9} \mathrm{~m}^{3}$ under the Negev, this implies a project life of about 150 years. Water cost in 1983 was found to be $\$ 0.15 / \mathrm{m}^{3}$ (investment, interest and maintenance included), similar to the costs of groundwater pumped from a deep well dug into the Lower Cretaceous Nubian Sandstone aquifer (Tushia, 1981; Issar and Melamed, 1983).

Naturally, such an enterprise would be dependent on many local factors: hydrological, social and economic. It is presented here to demonstrate that pumpage from a deep well is not necessarily the only method for mining fossil groundwater, and that sometimes a nonconventional approach may be worthwhile.

\section{Acquiring the Data: A Sequential Approach to the Negev}

Scarcity of data is the first and most crucial problem to be encountered when developing fossil aquifers beneath large and remote regions. This becomes even more acute because the magnitude of the water resource frequently calls for a very large project, requiring in turn a large investment that can be economically justified only after adequate exploration and research have yielded ample data. Generally this sequence closes into a vicious circle, because investment in exploration requires knowledge about the aquifer potential, and this demands further investment.

As groundwater mining is still a controversial issue among hydrogeologists, decision makers who seek technical advice before large sums are spent on exploration often face strong opposition to the development of these aquifers. To avoid hasty and costly development, a stage by stage program of

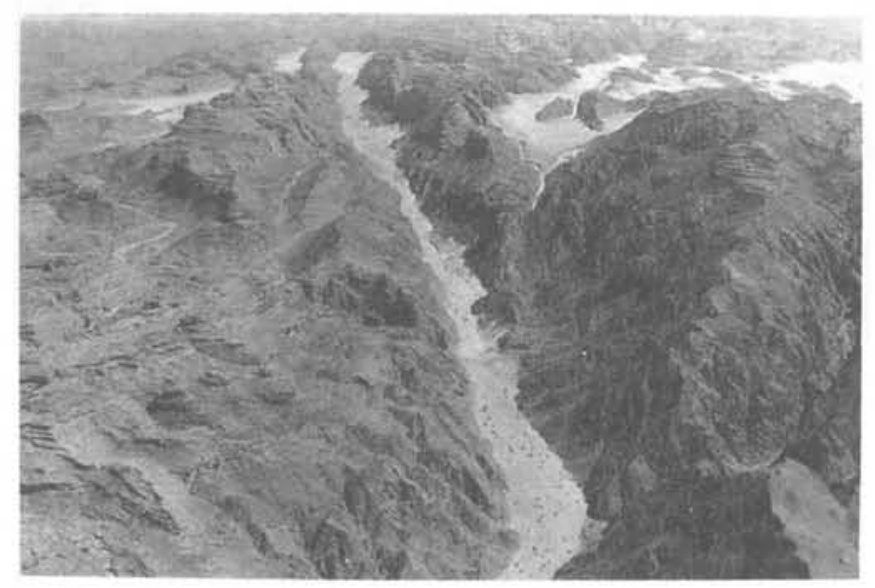

Figure 7: Aerial view of flat-lying Nubian Sandstone (on left) overlying basement granites in the central sinai, Egypt.

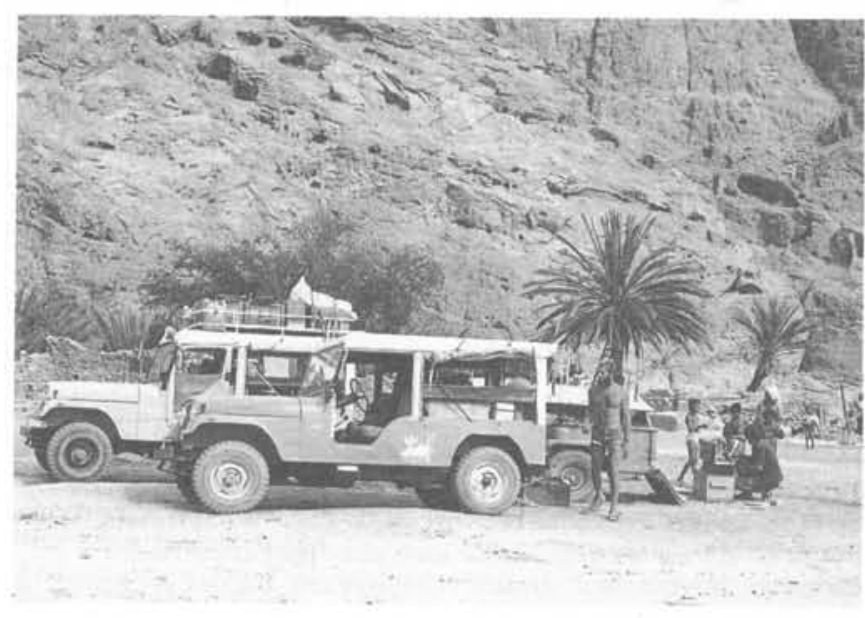

Figure 8: Field investigations in the central Sinai, Bgypt.

progressive exploration and investigation is needed to acquire data without big investments (Fig. 8). Such a sequence has been used in the study of the fossil aquifers in the Negev Desert and is presented here as a case study.

The concept of fossil groundwater beneath the Negev Desert first arose when a well that penetrated the Nubian Sandstone along the fault escarpment near the Dead Sea yielded an artesian flow. Arad (1966) suggested that the water in the Nubian Sandstone here originated by leakage from the overlying Judea aquifer (limestone and dolostone of Middle Cretaceous age), which is currently recharged in the Judea Mountains north of the Negev Desert. An alternative explanation (Issar et al., 1972) proposed that the water in the Nubian Sandstone in the Dead Sea area originally came from its outcrop area in Sinai, where recharge rate is extremely low because of the arid climate (Figs. 9 and 10 ).

The difference in estimates of water potential between the two alternatives has obvious significance. According to the leakage approach, the safe yield is about $10 \times 10^{6} \mathrm{~m}^{3} / \mathrm{yr}$ with no reserves, whereas the fossil-water concept implies groundwater flow toward the region estimated at $20 \times 10^{6} \mathrm{~m}^{3} / \mathrm{yr}$ from a total groundwater reserve of about $70 \times 10^{9} \mathrm{~m}^{3}$ underlying the Negev Desert. The choice between these interpretations was facilitated by an abandoned oil exploration well located in the Negev Highlands along the line between the Nubian Sandstone outerops in the Sinai and the Dead Sea (Fig. 9). Groundwater sampled from this well was found to be isotopically similar to that in the Nubian Sandstone in the Dead Sea area and to the paleowater of the Suez and Western Desert. This isotopic similarity and other hydrological considerations imply that water in the Nubian Sandstone at the Dead Sea area indeed originated from Sinai and not from the Judea Mountains (Issar et al, 1972).

Based on this information, a preliminary hydrological budget for the Dead Sea region was ealculated as a second stage activity (Rosenthal et al., 1978), including the calibration of calculated piezometric heads based on observed data. This was used for forecasting drawdown in wells due to pumpage in the Dead Sea area.

In the third stage, a conceptual and numerical model for the Nubian Sandstone aquifer for the entire Negev was formulated (Kreutero, 1980), requiring the definition of aquifer boundaries and boundary conditions. Preliminary estimates were possible because the aquifer was perceived as a regional one for which hydrogeological conditions can be considered fairly constant over wide regions. This study allowed the calculation of recharge and discharge for each zone, and the production of a regional potentiometric 


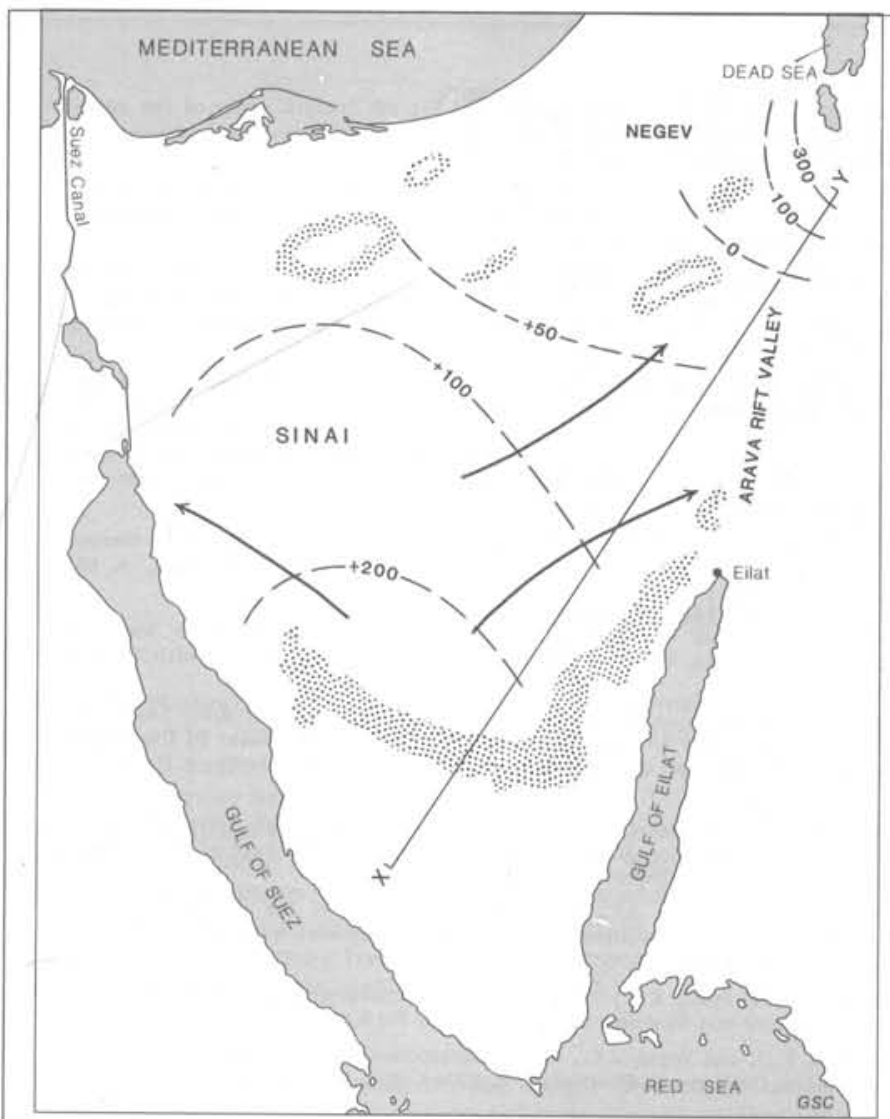

Figure 9: Groundwater flow (shown by arrows) in the Upper Cretaceous Nubian Sandstone of the Sinai, Egypt, and the Negev, Israel. Flow is from the aquifer outcrops (stippled) in the southern Sinai to the Suez Rift in the west and northwest, and towards the Arava Rift Valley in the east and northeast.

surface map, which was calibrated by data on piezometric head in observation wells. This study also improved the estimates of transmissivity and storativity distribution in the aquifer.

The fourth stage involved a detailed investigation of the aquifer in the Dead Sea region to explore water sources for an industrial and mining complex in this area. A three-layer (Middle and Lower Cretaceous, and Jurassic aquifers) multicell numerical model was constructed (Levin, 1984) to investigate the impact of pumpage from one aquifer on another, potential encroachment of Dead-Sea water as a result of over-pumpage, and the optimal distribution of pumpage over the Dead-Sea region.

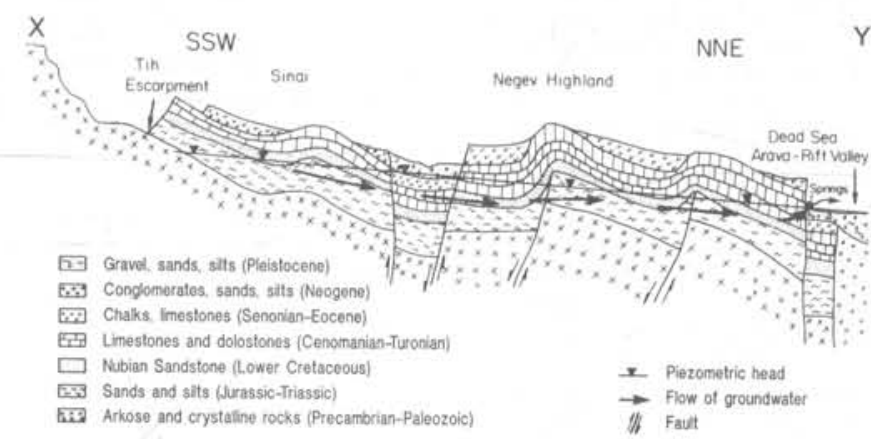

Figure 10: Schematic cross section of the hydrogeological system from the outcrops of the Nubian Sandstone aquifer in the southern sinai to the Dead Sea $(X-Y$ in Figure 9).
Hydrological studies during the fifth stage again included the whole Negev region. These explored, through data from 47 oil wells, the potential of additional fossil groundwater in the underlying (Jurassic to Paleozoic) aquifers and their hydraulic response to pumpage (Nativ, 1984). Lithological, hydrological and geochemical data were re-evaluated, and a special methodology for constructing a conceptual model for thick layered sequences with scarce data was developed (Nativ et al., 1987). On this basis a mathematical model was formulated and solved numerically (Nativ et al., in press). Results indicate that in the underlying Jurassic aquifer, additional reserves exist with hydraulic connections to the overlying Lower Cretaceous aquifer. In central and northern Negev, deeper aquifers in Triassic and Paleozoic rocks are, however, hydrologically separated from the two upper aquifers and contain only brines.

Currently, about $30 \times 10^{6} \mathrm{~m}^{3} / \mathrm{yr}$ is being pumped from the fossil aquifers of the Lower Cretaceous sandstone along the western boundary of the Arava Rift Valley between the Dead Sea in the north to the Gulf of Elat in the south. The overlying aquifers also provide about $30 \times 10^{6} \mathrm{~m} / \mathrm{yr}$ of renewable water to this area. The hydrological investigation described above indicates, however, that production from the fossil aquifers in the Negev area can be tripled if needed. At present, water development in this area is restricted not by water quantities, salinity or cost, but by the low priority placed by the government on such projects.

\section{Conclusion}

This review has addressed some of the problems encountered when considering the development of deep aquifers bearing non-renewable groundwater. As shown on Table 1, some of these aquifers have already been tapped in Africa and Australia, generally without a long-term development plan. We hope this article will contribute to extensive use of this huge water source in arid areas where groundwater is essential to development. The vulnerability of this source and of the arid environment requires, however, that their development be guided by careful regional hydrological, economic and sociological planning. In doing so it should be realized that the investigation of deep aquifers may also offer insights into paleo-environmental conditions that could prove valuable in developing other resources.

Professor A.S. Issar heads the Hydrogeology and Water Engineering Unit at the Jacob Blaustein Institute of Desert Research, and teaches at the Ben Gurion University of the Negev (Sede Boquer Campus, Israel 84,990). A former head of the Hydrogeological Division of the Geological Survey of Israel, he served four years as a FAO Advisor in Iran, and is a wellknown hydrological consultant in other developing count ries.

Dr. R. Nativ is based at the Seagram Centre for Soil and Water Sciences at the Hebrew University of Jerusalem (Rehovot 76-100, Israel). She studies the hydrology of arid zones, deep aquifers, the hydrochemistry of precipitation and surface water, and the subsurface isolation of radioactive wastes.
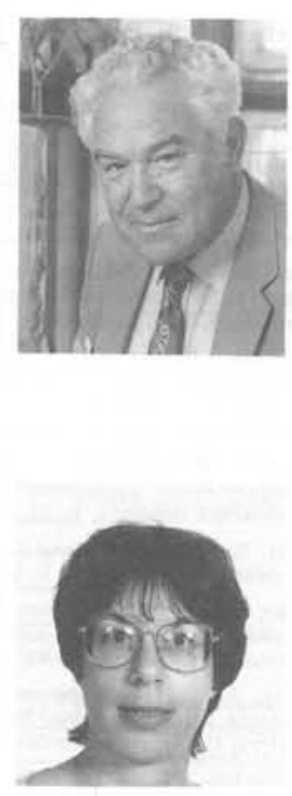


\section{References}

Ambroggi, R.P., 1966. Water under the Sahara. Scientific American, v. 214 , p. 21-29.

Arad, A., 1966. The geology and hydrogeology of the Lower Cretaceous in the northern Negev and Judea Mountains. Ph.D. Dissertation, The Hebrew Un:versity of Jerusalem, Israel, $154 \mathrm{p}$. (in Hebrew with English abstract).

Australian Water Resources Council, 1975. Ground water resources of Australia. Australian Government Publishing Service, Canberra, Australia, $143 \mathrm{p}$

Avigur, A., 1987. The geochemistry of trace elements and isotopes $(\mathrm{C}, \mathrm{O}, \mathrm{S}$ and $\mathrm{Pb}$ ) in the secondary carbonates of the Negev, Ph.D. Dissertation, Ben Gurion University of the Negev, Israel, $213 \mathrm{p}$. (in Hebrew with English abst ract).

Bakiewicz, W., Milne, D.M. and Noori, M., 1982. Hydrogeology of the Umm Er Radhuma aquifer, Saudi Arabia, with reference to fossil gradients. Quarterly Journal of Engineering Geology, v. 15, no. 2, p. 105-126.

Bartov, Y., 1974. A structural and paleogeographic study of the central Sinai faults and domes. Ph.D. Dissertation, The Hebrew University of Jerusalem, Israel, 143p. (in Hebrew with English abstract).

Beaumount, P., 1977. Water and development in Saudi Arabia. Geographical Journal, v. 143, Part 1, p. 42-60.

Burdon, D.J., 1977. Flow of fossil groundwater. Quarterly Journal of Fngineering Geology, v. 10, no. 2, p. 97-124.

Burdon, D.J. and otkun, G., 1968. Hydrogeological control of development in Saudi Arabia. In: Proceedings of the XXIII International Geological Congress, Section 12, p. $145-153$

Calf, G.E. and Habermehl, M.A., 1983. Isotope hydrology and hydrochemistry of the Great Artesian basin, Australia. In: Isotope Hydrology, 1983, Inter mational Symposium on Isotope Hydrology in Water Resources Development, Proceedings series. International Atomic Energy Agency, Vienna, p. 397-413.

Degens, E.T., 1962. Geochemische untersuchungen von wassern aus der agyptischen Sahara. Geologische Rundschau, v. 52, no. 2, D. 625-639.

Fontes, J.C., 1980. Environmental isotopes in groundwater hydrology. In: Fritz, P. and Fontes, J.C. (eds.), Handbook of Environmental Isotope Geochemistry, vol. 1, The Terrestrial Environment. Elsevier, Amsterdam, New York, p. 75$-134$

Fontes, J.C., 1981. Paleowaters. In: Gat, J.R. and Gonfiantini, R. (eds.), Stable Isotope Hydrology (Deuterium and Oxygen-18 in the Water Cycle), Technical Report Series No. 210. International Atomic Fnergy Agency, Vienna, p. 273298.

Forkasiewicz, J. and Margat, J., 1982. L'eploitation des reserves d'eau souterraine en zones aride et semi-aride. Fssai de synthese. Bulletin du BRGM, Section 3, v. 2, p. 115-126.

Gat, J.R., 1981a. Groundwater. In: Gat, J.R. and Gonfiantini, R. (eds.), Stable Isotope Hydrology (Deuterium and Oxygen-18 in the Water Cycle), Technical Report Series No. 210 . International Atomic Energy Agency, Vienna, p. 223240.

Gat, J.R., $198 \mathrm{lb}$. Paleoclimatic conditions in the Levant as revealed by the sotopic composition of paleowaters. Israel Meteorological Research Papers, v. 3 , p. $13-28$.

Gat, J.R. and Issar, A.S., 1974. Desert isotope hydrology: water sources of the Sinai Desert. Geochimica et Cosmochimica Acta, v. 38, p. 1117-1131.

Gonfiantini, R., Conrad, G., Eontes, J.C., Sauzay, G. and Payne, B.R., 1974 Etude isotopique de la nappe du continental intercalaire ef de ses relation avec les autres nappes du Sahara septentrional. In: Isotope Techniques in Groundwater Hydrology. International Atomic Energy Agency, Vienna, p. 22$7-241$.

Uabermehl, M.A., 1983. Hydrogenlogy and hydrochemistry of the Great Artesian Basin, Australia. In: Papers of the International Conference on Groundwater and Man, Australian Water Resources Council Conference Serjes. Australian Government Publishing Service, Canberra, no. 8, p. 83-98.

Hlimidia, I.H., 1970. The Nubian artesian hasin, its regional hydrogeological aspects and palneohydrological reconstruction. New Zealand Journal of Hydrology, v. 9, D. 89-116.

Himidia, I.H. and Diab, M.S., 1979. A regional hydrogeochemical study of the artesian water aquifers in the Westem Desert of Egypt. In: GEOCOME-I, Firs Geological Congress of the Viddle East, Mineral Resources and Exploration Institute and Geological Society of Turkey, Ankara, Turkey, D. 297-314.

Ilani, S., Flexer, A. and Kronfeld, J., 1987a. Copper mineralization in sedimentary cover associated with tectonic elements and volcanism in Israel Mineralium Deposita, v. 22 , no, 4, p. 269-277.

Ilani, S., Kronfeld, J. and Pinchasov, A., 1987b. Uranium distribution in iron veins in Israel. Uranium, v. 4, no. 2, p. 159-174.

Issar, A.S., 1979. The paleohydrology of southern Israel and its influence on the flushing of the Kurnub and 4 rad Groups (Lower Cretaceous and Jurassic). Journal of Hydrology, v. 44, no. 3-4, p, 289-303.

Issar, A.S., 1981a. The role of non-replenishable aquifers in development projects in arid regions. In: Berkofsky, L., Faiman, D. and Ciale, J. (eds.) Settling the Deserts. Gordon Breach, London, New York, Paris, p. 117-128.

Issar, A.S., 1981b. The rate of flushing as a major factor in determining the chemistry of water in fossil aquifers in southern Israel. Journal of Hydrology, v. 54 , no. $1-3$, p. $285-296$

Issar, A.S., 1983. Emerging ground water, a triggering factor in the formation of the Jakhteshim (erosion cirques) in the Negev and Sinat. Isrnel Journal of Earth Se.ences, v. 32 , p. $53-6$ !
Issar, A.S., Bein, A. and Michaeli, A., 197\%. On the ancient water of the upper Nubian Sandstone aquifer in central Singi and southern Israel Journal of Hydrology, v. 17 , no. 4, D. 35.3-374.

Issar, A.S. and Bruins, H.J., ] 983. Speeial climatologienal conditions in the deserts of Sinai and the Negev during the latest Pleistoceno. Palaengeography, Palaenclimatology, Palaeoecology, v. 43, no. 1-2, p. 63-7?

Issar, A.S. and Melamed, A., 1983. The use of galleries for the mining of water from the Nubian Sandstone aquifer in the Negev, istapl. VI World Congress of Engineers and Architects on Developinent of Desert and Sparsely Populated Areas, Tel Aviv, unpaginated.

Issar, A.S. and Gilead, I., 1986. Pleistocene climates and hydrology of the Negev (Israel) and Sinai (Erypt) deserts. In: Impact of climatic variations on East Saharian groundwaters-modelling of large seale flow regime. Proceedings of a Workshop on Hydrology organized by the Special Research Project Arid areas at the Technical University Berlin, 1985. Verlag von Dietrich Reimer, Berlin, p. 17-25.

Klitzsch, E., Sonntag, C., Weistroffe, K. and El-Shazly, E.M., 1976. Crundwasser der Zentralsahara: Fossil Vorraete. Geologische Rundsehau, v. 65 no. 1, P. $264-287$

Kreutero, L., 1980. The hydrogeology of the Nubian Sandstone in southern Israel. M.Se. Thesis, Tel Aviv University, Israel, 45p. (in Hebrew with English abstract).

Leguy, C., Rindsberger, M., Zangwil, A., Issar, A.S. and Gat, J.R., 1983. The relation between the 180 and deuterium contents of rain water in the Negev Desert and air-mass trajectories. Isotope Geoseience, 1983, v. 1, no. 3 p. 205-218.

Levin, O., I984. Behaviour of an aquifer system with special reference to the northern Arava aquifers. M.Sc. Thesis, Technion-Israel Institute of Teehnology, $168 \mathrm{p}$ (in Hebrew with English abstract).

Lloyd, J.w. and Miles, J.C., 1986. An examination of the mechanisms controlling groundwater gradients in hyper-arid regional sedimentary basins. Water Resources Bulletin, v. 22, no. 3, p. 471-478.

Margat, J, and Saad, K.F., 1984. Deep-lying aquifers: water mines under the desert? Nature and Resources, v. 20, no. 2, p. 7-13.

Munnich, K.O. and Vogel, J.C., 1962. Untersuchungen an pluvialen wassern der Ost-Sahara. Geologisehe Rundschau, v. 52, no. 2, p. 611-624.

Nativ, R., 1984. The water potential of the deep Jurassic to Paleozoic aquifer in the Negev, Israel. Ph.D. dissertation. Ben Gurion University of the Negev, Israel, $31 \mathrm{lp}$. (in Hebrew with English abstract).

Nativ, R., Bachmat, Y, and Issar, A.S., 1987. Potential use of the deep aquifers in the Negev Desert - a conceptual model. Journal of Hydrology, v. 94, no. 3-4, p. $237-265$

Nativ, R., Bachmat, Y. and Dax, A., in press. Potential use of the deep aquifers in the Negev desert - a mathematical model and its numeric solution. Journal of Hydrology.

Reboucas, A., 1978. Le grand bassin hydrogeologique du maranhao-Bresil, perspectives sur l'exploitation. In: Hydrogeology of Great Sedimentary Basins, International Association of Hydrogeologists, Memoires, v. 11, p. 448-461. Hungarian Geological Institute, Budapest.

Rosenthal, E., Gilead, D., Chetboun, G. and Issar, A.S., 1978. Hydrogeology of the Kurnub Group in the Dead Sea area. Hydrological Service of Israel, Hydrological Report 1978/1, Jerusalem, 33p. (in Hebrew).

Said, R., 1962. The Geology of Egypt. Elsevier Pub. Co., Amsterdam-New York, $377 \mathrm{p}$.

Senior, B.R. and Habermehl, M.A., 1980. Structure, hydrodynamics and hydrocarbon potential, central Eromanga Basin, Queensland, Australia. Journa of Australian geology and Geophysics, v. 5 , no. 1, p. 47-55.

Shraga, M.G., 1971. The hydrothermal iron deposits of the Tenuha Ridge. Israel Journal of Earth Sciences, v. 20, no. 2, p. 51-87.

Sonntag, C., Klitzsch, E., Lohnert, E.P., El-Shazly, E.M., Munnich, K.O. Junghans, C., Thorweihe, U., Weistroffer, K. and Swailem, F.M., 1978. Palgeoclimatic information from deuterium and oxygen-18 in earbon-14 dated North Saharian groundwaters. In: Isotope Hydrology, Proceedings of a Symposium, Neuherberg. International Atomic Energy Agency, Vienna, p. 569-580.

Tsur, Y. and Issar, A.S., in press. The buffer role of ground water when supply of surface water is uncertain. In: Ground Water Economics, International Symposium and Workshop on Ground Water Economics, Barcelona, 1987, UN Department of Technical Cooperation for Development.

Tushia-Consulting Engineers Ltd., 1981. Feasibility study of the inclusion of the Nubian Sandstone aquifer in the Negev as a major water source in the national water supply system, 64p. with unpaginated appendices (in Hebrew).

Williams, A.F. and Holmes, J.W., 1978. A novel method of estimating the discharge of water from mound springs of the Great Artesian Basin, centra Australia. Journal of Hydrology, v. 38, no. 3-4, p. 263-272.

Wright, E.P., 1983. Ground water development. In: World Water 83 . Thomas Telford Ltd., London, p. 63-71.

Wright, E.P., Benfield, A.C., Edmunds, W.M. and Kitching, R., 1982. Hydroreology of the Kufra and Sirte basins, eastern Libya. Quarterly Journal of Engineering Geology, v. 15, no. 2, p. 83-103. 